\title{
A Molecular Docking of New 9ק-Halogenated Prostaglandin Analogs with an Ester Group at C-6 Atom of the $\alpha$-Side Chain
}

\section{CONSTANTIN I. TANASE*, LUCIA PINTILIE, ELENA MIHAI}

National Institute for Chemical-Pharmaceutical Research and Development, Department of bioactive substances and pharmaceutical technologies, 112 Vitan Av., 031299 Bucharest-3, Romania

Abstract: Prostaglandins with cytoprotective activity were studied for a long time and a few $P G E_{1}$ and $P G E_{2}$ stable analogs were promoted as drugs: arbaprostil, enprostil, misoprostol and rioptostol. Nocloprost, a 9 $\beta$-chlorine prostaglandin analog, has been also promoted as a cytoprotective drug; the succes with this compound stimulated the reserches, and many $9 \beta$-or $11 \beta$-substituted prostaglandins were synthesized and studied for their biological activity. In the same dirrection we previously synthesized new 9 3 -halogenated prostaglandins having also an ester group at the carbon atom 6. These compounds were now used in a molecular docking study to predict their potential cytoprotective (anti-ulcer) activity. The study has been done with CLC Drug Discovery Workbench 2.4. software and an oxidoreductase enzyme receptor, chosen from the Protein Data Bank, ID: 4KEW. Two recognized drugs, omeprazole (co-crystallized with the enzyme) and nocloprost were used as standard in the study. The $9 \beta$-halogenated prostaglandin analogs were finally docked. Nocloprost and all $9 \beta$ halogenated compounds had docking score greater than that of omeprazole. The majority of the $9 \beta$ halogenated analogs have a docking score even greater than that of nocloprost, indicating that these compounds could have potential cytoprotective activity. Correlations between docking score and substituents on the prostaglandin skeleton have been done.

Keywords: 9ק-halogenated prostaglandins; molecular docking; nocloprost; omeprazole; oxidoreductase enzyme receptor $4 \mathrm{KEW}$; docking score; cytoprotective (anti-ulcer) activity.

\section{Introduction}

Prostaglandins with cytoprotective activity were studied for a long time and a few $\mathrm{PGE}_{1}$ and $\mathrm{PGE}_{2}$ stable analogues were promoted as drugs: arbaprostil [1], enprostil [2], misoprostol [3] and rioptostol [4,5]. The compounds had secondary effects, mainly: diarrea, stimulation of uterine contraction, abdominal pain. So, other modified prostaglandin compounds, halogenated with chlorine, fluorine and bromine at 9 ( $9 \alpha$ or $9 \beta)$ or 11 (11 $\alpha$ or $11 \beta)$ position of the cyclopentane ring of prostaglandins and also at the $\omega$-side chain were synthesized [6-9] and their biological activity was determined. "Nocloprost" exhibits cytoprotective (anti-ulcer) activity [10] but other compounds, ZK-118182 [11], ZK-110841 $[12,13]$ and flunoprost have antitrombotic activity, 13,14-dihydro-ZK-110841 (AL-6556) [14] (Figure 1) reduces intraocular pressure, etc.
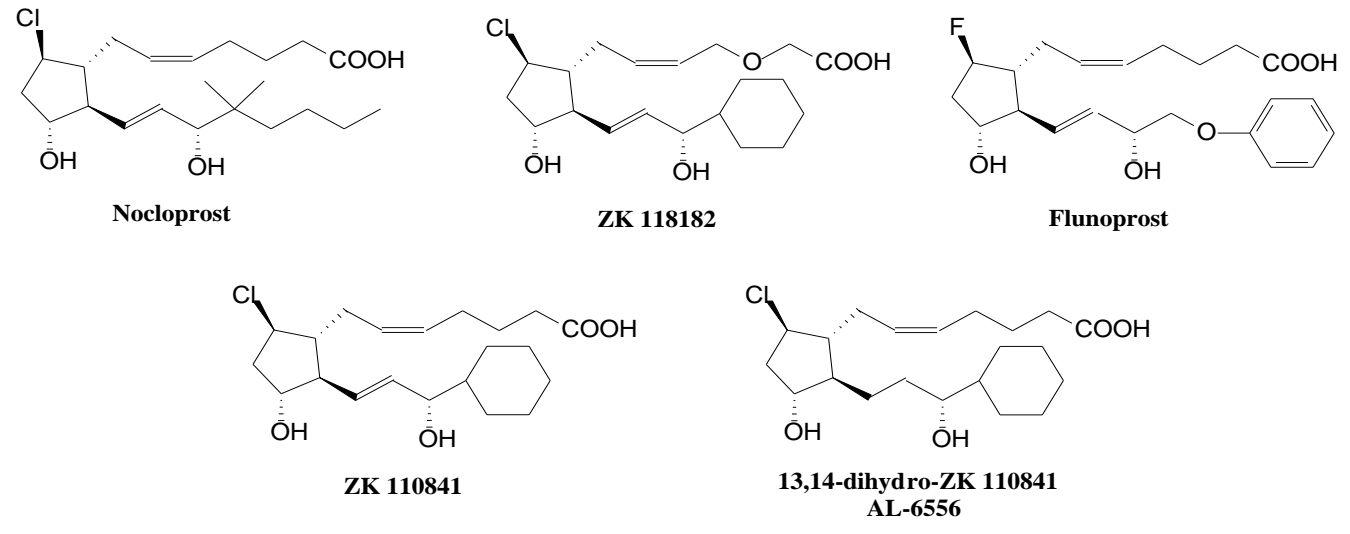

Figure 1.

Biological active

9-halogenated prostaglandin analogues

\footnotetext{
*email: cvtanase@gmail.com
} 
9-Halogenated prostaglandins mimic the 9-keto group and acts at the receptors of $\mathrm{PGE}_{2}$ (Nocloprost is in this group of prostaglandin analogs) and 11-halogenated prostaglandins have great affinity for receptors of $\mathrm{PGD}_{2}$, like for example compound $\mathrm{ZK} 110841$. In the same dirrection we previously synthesized $9 \beta$-halogetaned prostaglandins and the results were published in a paper [15] and a patent request [16]. Brossing the literature, a molecular docking study of the 9-halogenated prostaglandins had not been found for predict their cytoprotective (anti-ulcer) activity.

\section{Materials and methods}

The docking studies have been realized according to the docking protocol [18]: importation of the protein/enzyme receptor, preparation of the protein receptor, setup the binding site and setup the binding pocket, introduction of the ligands in the "Molecule Project", docking the ligands in the active binding site, extraction of the docked ligands in to a "Molecule Table", calculation of the molecular properties of the ligands, screening the docking results. The validation of the method and of the docking parameters acquired from the molecular docking studies, have been carried out by redocking the co-crystallized docked in the active binding site of the protein receptor. The docking score and the hydrogen bonds established with the amino acids from the group of interaction are used to predict the binding modes, the binding affinities and the orientation of the docked compounds in the active site of the protein/enzyme receptor. The molecular properties of the small molecules, such as parameters of the Lipinski's rule of five: the molecular weight, number of hydrogen bond donors, number of hydrogen bond and Log P (octanol-water partition coefficient), have been calculated using the "Calculate Molecular Properties" tool [22].

\section{Results and discussions}

The paper was taken in the study a molecular docking to predict the cytoprotective (anti-ulcer) activity of the $9 \beta$-halogenated prostaglandins of type 2 and 3 . The compounds were obtained by oppening the $\delta$-lactone group of compounds 1 with diols $(n=0$ to 4$)$, or 2-butyn-1,4-diol, catalyzed by toluenesulfonic acid (Scheme 1), with the formation of an ester having an alcohol group at C-1 (prostaglandin numbering) spaced to carboxylic group by two to six methylene group or a 2-butyn group. The compounds have not only a $9 \beta$-halogen $(\mathrm{Cl}, \mathrm{Br}$ and $\mathrm{F})$ to act at the $\mathrm{PGE}_{2}$ receptors, but also an ester group at the carbon atom 6. Such an ester group was presented in the literature and the $\mathrm{PGE}_{2}$ type compounds showed cytoprotective activity [17] and the synthesized compounds presented in Scheme 1, having both modifications in the molecule, are waiting to have also cytoprotective activity.

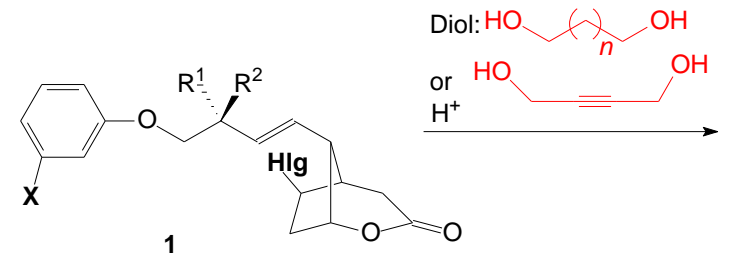

(1)

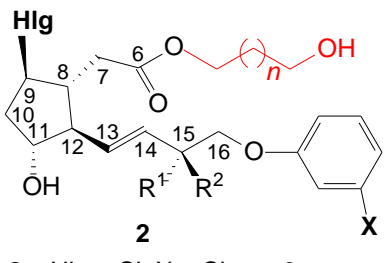

2a, $\mathrm{Hlg}=\mathrm{Cl}, \mathrm{X}=\mathrm{Cl}, n=0$ 2b, $\mathrm{Hlg}=\mathrm{Cl}, \mathrm{X}=\mathrm{Cl}, n=1$ 2c, $\mathrm{Hlg}=\mathrm{Br}, \mathrm{X}=\mathrm{Cl}, n=1$ 2d, $\mathrm{Hlg}=\mathrm{F}, \mathrm{X}=\mathrm{Cl}, n=1$ 2e, $\mathrm{Hlg}=\mathrm{Cl}, \mathrm{X}=\mathrm{Cl}, n=2$ 2f, $\mathrm{Hlg}=\mathrm{Cl}, \mathrm{X}=\mathrm{CF}_{3}, n=2$ 2g, $\mathrm{Hlg}=\mathrm{Br}, \mathrm{X}=\mathrm{Cl}, n=2$ $2 \mathrm{~h}, \mathrm{Hlg}=\mathrm{F}, \mathrm{X}=\mathrm{Cl}, n=2$ 2i, $\mathrm{Hlg}=\mathrm{Cl}, \mathrm{X}=\mathrm{Cl}, n=3$

2j, $\mathrm{Hlg}=\mathrm{Cl}, \mathrm{X}=\mathrm{Cl}, n=4$

2k, $\mathrm{HIg}=\mathrm{Cl}, \mathrm{X}=\mathrm{Cl}, n=2, \mathrm{R}^{1}=\mathrm{OH}$,

$\mathrm{R}^{2}=\mathrm{H}$

2l, $\mathrm{Hlg}=\mathrm{Cl}, \mathrm{X}=\mathrm{CF}_{3}, n=2, \mathrm{R}^{1}=\mathrm{OH}$

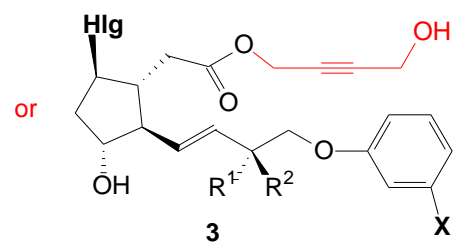

3a, $\mathrm{Hlg}=\mathrm{Cl}, \mathrm{X}=\mathrm{Cl}, \mathrm{R}^{1}, \mathrm{R}^{2}=\mathrm{O}$

3b, $\mathrm{Hlg}=\mathrm{Cl}, \mathrm{X}=\mathrm{CF}_{3}, \mathrm{R}^{1}, \mathrm{R}^{2}=\mathrm{O}$

3c, $\mathrm{Hlg}=\mathrm{Cl}, \mathrm{X}=\mathrm{Cl}, \mathrm{R}^{1}=\mathrm{OH}$ $\mathrm{R}^{2}=\mathrm{H}$

3d, $\mathrm{Hlg}=\mathrm{Cl}, \mathrm{X}=\mathrm{CF}_{3}, \mathrm{R}^{1}=\mathrm{OH}$ $\mathrm{R}^{2}=\mathrm{H}$

Scheme 1. Synthesis of $9 \beta$-halogenated prostaglandin analogues of type $\mathbf{2}$ and $\mathbf{3}$ 
To put in evidence their predicted cytoprotective activity, we have done a molecular docking study, using CLC Drug Discovery Workbench 2.4. software [18]. It is to be mentioned that in the literature we didn't found a similar molecular docking for Nocloprost or for other 9 or 11-halogenated prostaglandins.

The affinity of a compound to an identified protein or enzyme target is consider a relevant parameter in the process for development of a new drug. The prediction of the mode of binding of the ligand (generally, compounds in study) to the target (protein/enzyme) by molecular simulation could allow the restricting of the organic synthesis to the most promising chemical compounds.

We chose the 9 $\beta$-halogenated prostaglandin analogues $\mathbf{2 a - 2 l}$ and 3a-3d, presented in Scheme 1, for the molecular docking study. The computational molecular simulation was performed to determine the affinity and orientation of the compounds and their mode of binding to an oxidoreductase enzyme receptor, chosen from the Protein Data Bank, ID: $4 K E W$. (www.rcsb.org) [19]. In the study we used as standard two recognized drugs, omeprazole (co-crystallized with the enzyme) and nocloprost ( $\mathrm{F}_{2 \alpha}$ prostaglandin analogue with a $9 \beta$-chlorine atom instead of $9 \alpha-\mathrm{OH}$ group, Figure 1).

As usual, the binding site and binding pockets, used in the molecular docking of the ligands, were well established, and the search was carried out inside the binding site volume (Figure S1a, green sphere). The protein receptor, ID: $4 K E W$ was loaded from Protein Data Bank, water molecules were removed, omeprazole co-crystallized was extracted, the binding site and also the binding pocket (which play an important role in orientation during molecular docking) were defined. The cocrystallized omeprazole was reposed in the protein pocket, docking validation and hydrogen bonds between co-crystallized omeprazole and amino acid residues of receptor were done. The prostaglandin analog drug nocloprost, used as standard in the study, then has been docked and the results are presented in Table 1 (entry 2); docking pose of the interactions between nocloprost and the amino acid residues are presented in Figure 2.

Table 1. Docking score and the molecular properties of ligands: omeprazole, nocloprost, $9 \beta-$ halogenated prostaglandin analogs: 2a-2l and 3a-3d, calculated with CLC Drug Discovery Workbench 2.4 software

\begin{tabular}{|c|c|c|c|c|c|c|c|c|c|}
\hline $\begin{array}{c}\text { Compound } \\
\text { (Ligand) }\end{array}$ & Score & RMSD & $\begin{array}{c}\text { Atoms } \\
\text { No. }\end{array}$ & $\begin{array}{c}\text { Weight } \\
\text { [Daltons] }\end{array}$ & $\begin{array}{c}\text { Flexible } \\
\text { bonds }\end{array}$ & $\begin{array}{c}\text { Lipinski } \\
\text { violation }\end{array}$ & HD & HA & Log P \\
\hline $\begin{array}{c}\text { Omeprazole } \\
\text { (co-crystallized) }\end{array}$ & -58.11 & 0.06 & 41 & 328.41 & 5 & 0 & 0 & 5 & 3.28 \\
\hline Nocloprost & -71.25 & 1.32 & 64 & 400.98 & 12 & 1 & 3 & 4 & 5.38 \\
\hline $\mathbf{2 a}$ & -66.93 & 1.02 & 49 & 417.28 & 10 & 0 & 2 & 6 & 2.35 \\
\hline 2b & -73.00 & 0.83 & 52 & 431.31 & 11 & 0 & 2 & 6 & 2.71 \\
\hline 2c & -70.67 & 1.18 & 52 & 475.76 & 11 & 0 & 2 & 6 & 2.88 \\
\hline $\mathbf{2 d}$ & -74.92 & 0.78 & 52 & 414.85 & 11 & 0 & 2 & 6 & 2.46 \\
\hline $\mathbf{2 e}$ & -74.67 & 0.83 & 55 & 445.33 & 12 & 0 & 2 & 6 & 3.06 \\
\hline $\mathbf{2 f}$ & -74.92 & 0.43 & 58 & 478.89 & 13 & 0 & 2 & 6 & 3.32 \\
\hline $\mathbf{2 g}$ & -67.73 & 1.67 & 55 & 489.78 & 12 & 0 & 2 & 6 & 3.23 \\
\hline $\mathbf{2 h}$ & -73.63 & 0.92 & 55 & 428.88 & 12 & 0 & 2 & 6 & 2.82 \\
\hline $\mathbf{2 i}$ & -72.29 & 1.60 & 58 & 459.36 & 13 & 0 & 2 & 6 & 3.42 \\
\hline $\mathbf{2 j}$ & -71.13 & 1.36 & 61 & 473.39 & 14 & 0 & 2 & 8 & 3.78 \\
\hline $\mathbf{2 k}$ & -75.03 & 0.76 & 57 & 447.35 & 12 & 0 & 3 & 6 & 2.72 \\
\hline $\mathbf{2 1}$ & -77.57 & 1.25 & 60 & 480.90 & 13 & 0 & 3 & 6 & 2.97 \\
\hline 3a & -75.09 & 1.42 & 51 & 441.30 & 11 & 0 & 2 & 6 & 2.41 \\
\hline 3b & -82.27 & 0.63 & 54 & 474.85 & 12 & 0 & 2 & 6 & 2.66 \\
\hline 3c & -77.47 & 0.41 & 53 & 443.32 & 11 & 0 & 3 & 6 & 2.06 \\
\hline 3d & -84.91 & 1.28 & 56 & 476.87 & 12 & 0 & 3 & 6 & 2.32 \\
\hline
\end{tabular}

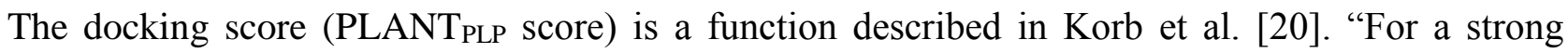
binding, the score has a negative value; for weak or non-existing binding, the score has a less negative or even positive value" [21]. 


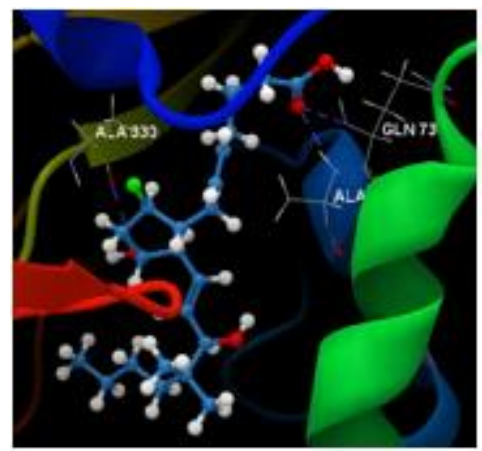

a

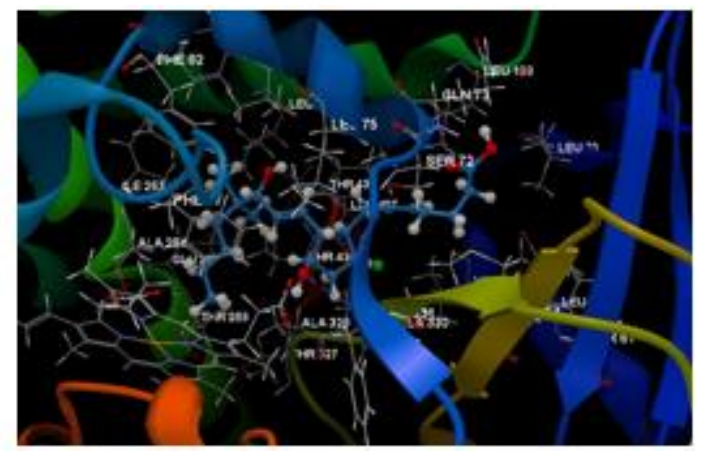

b

Figure 2. a) Hydrogen bonds between the amino acid residues ALA 330, ALA 74 and GLN 73 of the receptor and Nocloprost; b) Docking pose of Nocloprost ligand interacting with amino acid residues in the binding site

The 9 $\beta$-halogenated prostaglandin analogs $\mathbf{2 a - 2 l}$ and 3a-3d, presented in Scheme 1, were finally docked and the results of the calculated properties (flexible bonds, Lipinski violations, the number of hydrogen bond donors, the number of hydrogen bond acceptors and $\log \mathrm{P}$ ) are presented in Table 1 . The calculated parameters can predict if a molecule possesses properties that might turn it into an active drug, according to the Lipinski's rule of five [22,23]: 1) the number of hydrogen donors $(\mathrm{N}-\mathrm{H}$ and $\mathrm{OH}$ ) to be $<5,2$ ) the number of acceptors hydrogen $<10,3)$ molecular weight $<500 \mathrm{Da}, 4)$ the octanol-water partition coefficient [23] $(\log P)<5$. The number of violations of the Lipinski rules give a guidance to evaluate drug-likeness for a molecule (if a molecule has chemical and physical properties to become a likely active orally active drug) [20,23]; omeprazole is taken as an example of a drug that confirms to this five's Lipinski rules. According to the data presented in Table 1, all 9 $\beta$ halogenated compounds comply with the Lipinski rules (Lipinski violation is 0 ), and nocloprost drug have one violation [20,23]. In Table 1, the docking score (and RMSD, which is $<2$ ) is also presented. All 9 $\beta$-halogenated analogs and nocloprost also have docking scores greater than that of omeprazole (58.11 , RMSD 0.06). The majority of the $9 \beta$-halogenated analogs have a docking score greater than that of $9 \beta$-chlorine nocloprost prostaglandin recognized drug (-71.25, RMSD 1.32), used as standard in the study, with the exception of the compounds 2a (-66.93, RMSD 1.01), 2c (-70.67, RMSD 0.83), 2g (67.73, RMSD 1.67) and 2j (-71.13, RMSD 1.36) (See also Fig. 3). Basing on the docking score, the study shows that the cytoprotective (anti-ulcer) activity of the compounds $\mathbf{2 b}, \mathbf{2 d - 2 f}, \mathbf{2 h}-\mathbf{2 i}, \mathbf{2 k} \mathbf{k} \mathbf{2} \mathbf{l}, \mathbf{3 a}-$ $\mathbf{3 d}$ is greater than that of nocloprost. A few other observations should be mention:

- 3-(CF -phenoxy) are more active than 3-chloro-phenoxy substituted compounds (2f $(-74.92)>$ 2e (-74.67); 2l (-77.57) > 2k (-75.03); 3b (-82.27) > 3a (-75.09); 3d (-84.91) > 3c (- 77.47)).

- the length of the alkyl spacer between the 6-ester group and the hydroxyl group influence the anti-ulcer activity, in the order: $\mathbf{2 a}(n=0 ;-66.93)<\mathbf{2 b}(n=1 ;-73.00)<\mathbf{2 l}(n=2 ;-74.67)>\mathbf{2 i}(n=3$; $72.29)>2 \mathbf{j}(n=4 ;-71.13)$, most active being the compound $2 \mathbf{l}$, with a similar length of eight atoms (with the oxygen group of the ester) to that of known in the $\alpha$-side chain of natural prostaglandins.

by reduction of 15-keto group to $15 \alpha-\mathrm{OH}$ group, the docking score increase: -74.67 docking score of $2 \mathbf{e}$ increase to -75.03 for $\mathbf{2 k}$ and -74.92 docking score for $\mathbf{2 f}$ increase to -77.57 for $\mathbf{2 l}$; the same is for 2-butyn synthon of compounds $\mathbf{3 a - 3 d} \mathbf{- 3}-75.09$ for $\mathbf{3 a}$ increase to -82.27 for $\mathbf{3 b}$ and -77.47 for $\mathbf{3 c}$ increase to -84.91 for $3 d$.

- the influence of the $9 \beta$-halogen on the docking score is clear for keto-compounds: F (2d, 74.92) > Cl (2b, -73.00) > Br (2c, -70.67); for the 15-OH allylic alcohols, the chlorine substituted analog has a docking score $(\mathbf{2 e},-74.67)$ greater than that of the fluorine analog $(\mathbf{2 h},-\mathbf{7 3 . 6 3 )}$ and the bromine analog has the smaller value for docking score $(\mathbf{2 g},-67.73)$.

- The compounds with a 2-butyn scaffold (3a-3d) in $\alpha$-side chain had a docking score greater than that with a linear chain $(\mathbf{2 a - 2 l})$. 
- $\quad$ the compound $\mathbf{3 d}$ had the best score (-84.91), followed by compound $\mathbf{3 b}(-82.27)$, compounds with a 2-butyn synthon in $\alpha$-side chain; for compounds with normal $\alpha$-side chain, the best score is for the compound $2 \mathrm{l}$ (-77.57).

An expressive presentation of the docking score is presented in Figure 3:

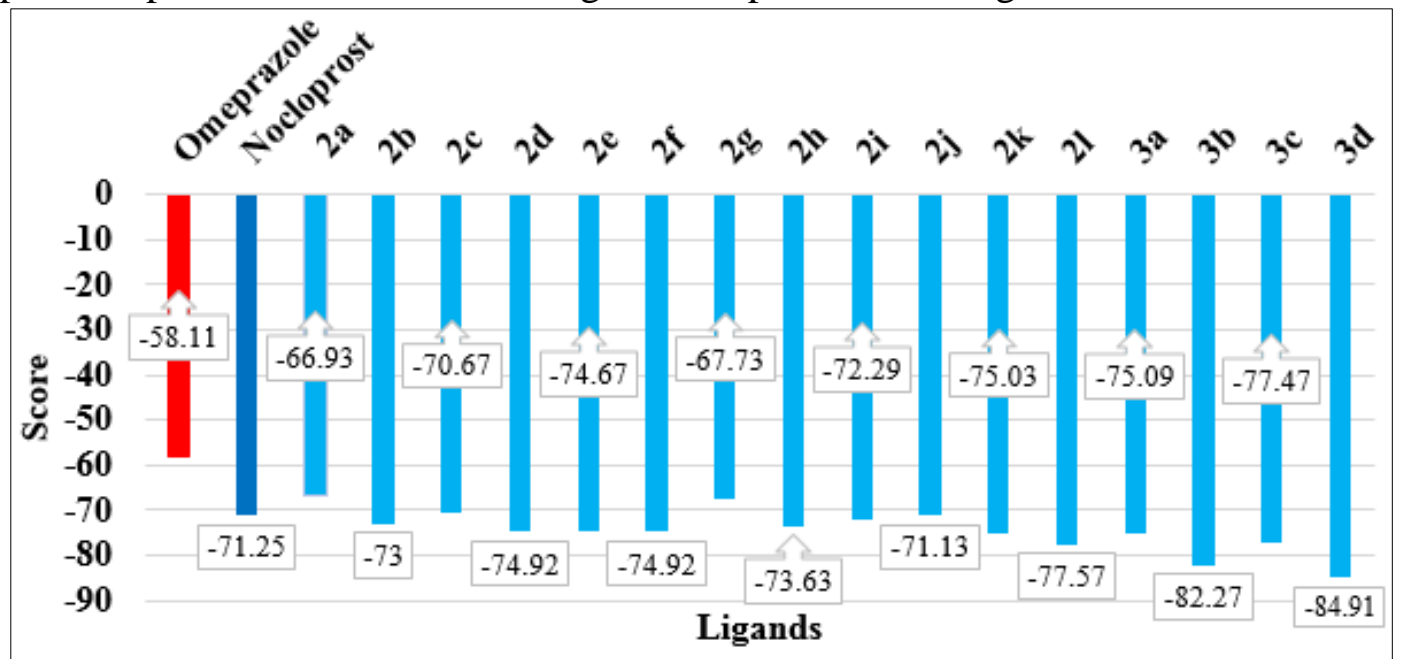

Figure 3. Docking score of the $9 \beta$-halogenated prostaglandin compounds $\mathbf{2 a - 2 l}$ and 3a-3d by comparison with the docking score of two cytoprotective (anti-ulcer) recognized drugs: omeprazole and nocloprost.

Besides the parameters mentioned in Table 1, group interaction, hydrogen bonds of ligands with amino acid residues were determined and hydrogen bond length was calculated. These are presented in the Table 2.

The docking poses of the ligands with the best score interacting with the amino acid residues of the protein are presented as follows: 3d in Figure 4, 3b in Figure 5, 3c in Figure 6 and $2 \mathbf{l}$ in Figure 7.

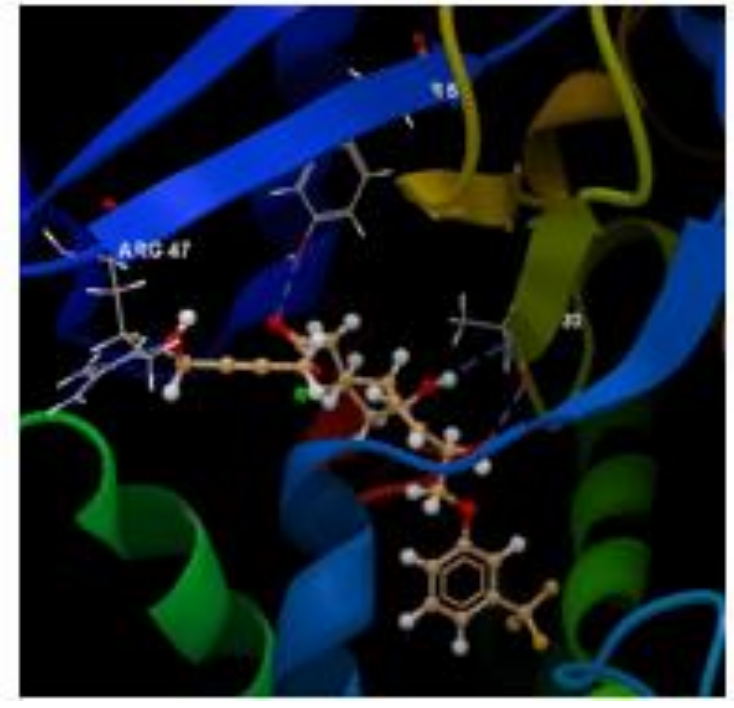

a

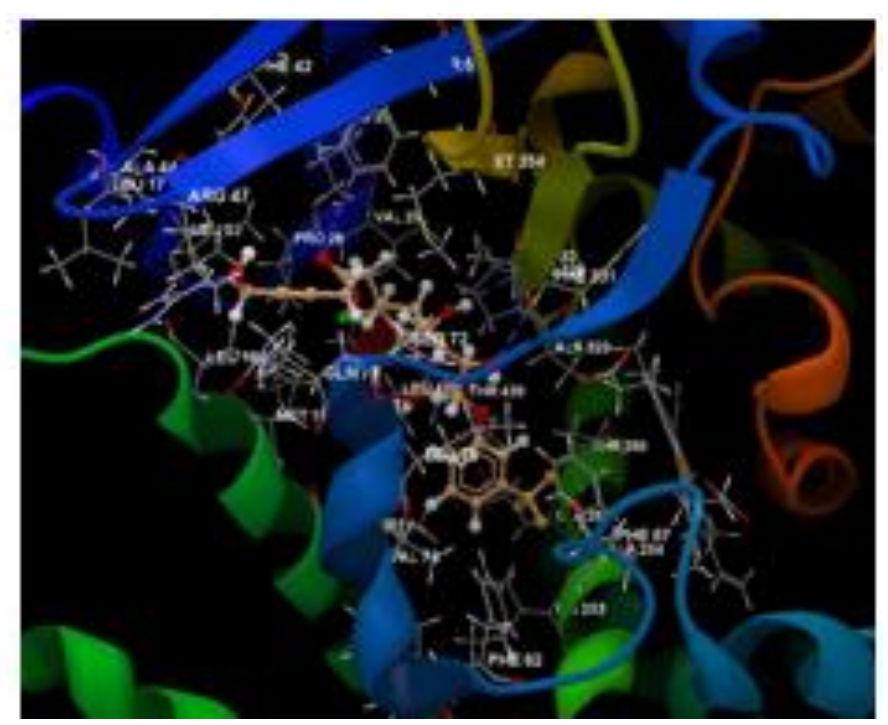

b

Figure 4. a) Hydrogen bonds between the residues of the ALA 330, TYR 51 and ARG 47 and the compound 3d; b) Docking pose of the compound 3d interacting with amino acid residues in the binding site 

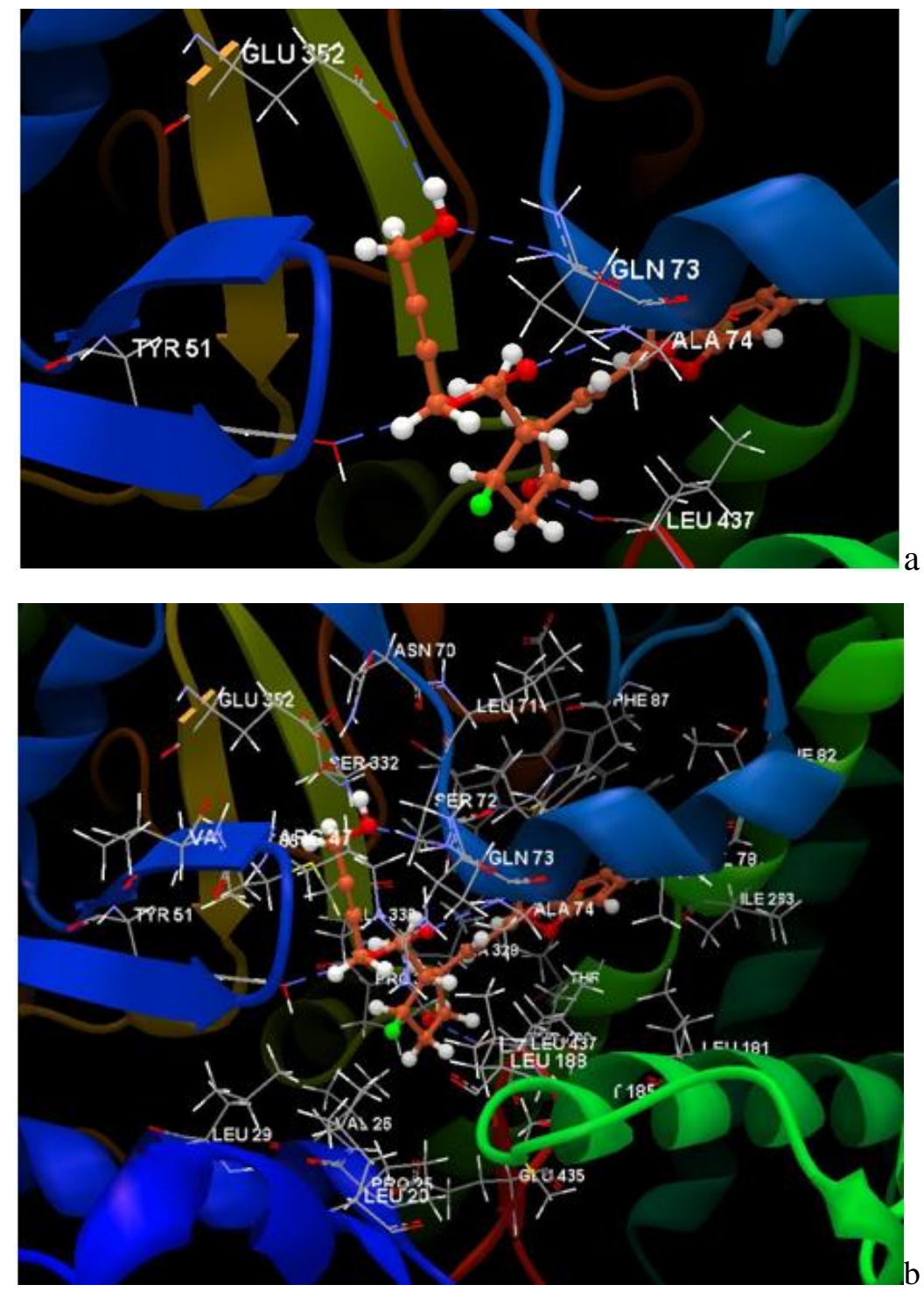

Figure 5. a) Hydrogen bonds between the residues of the TYR 51, ALA 74, GLN 73, LEU 437 and GLU 352 and the compound 3b; b) Docking pose of the compound $\mathbf{3 b}$ interacting with amino acid residues in the binding site.

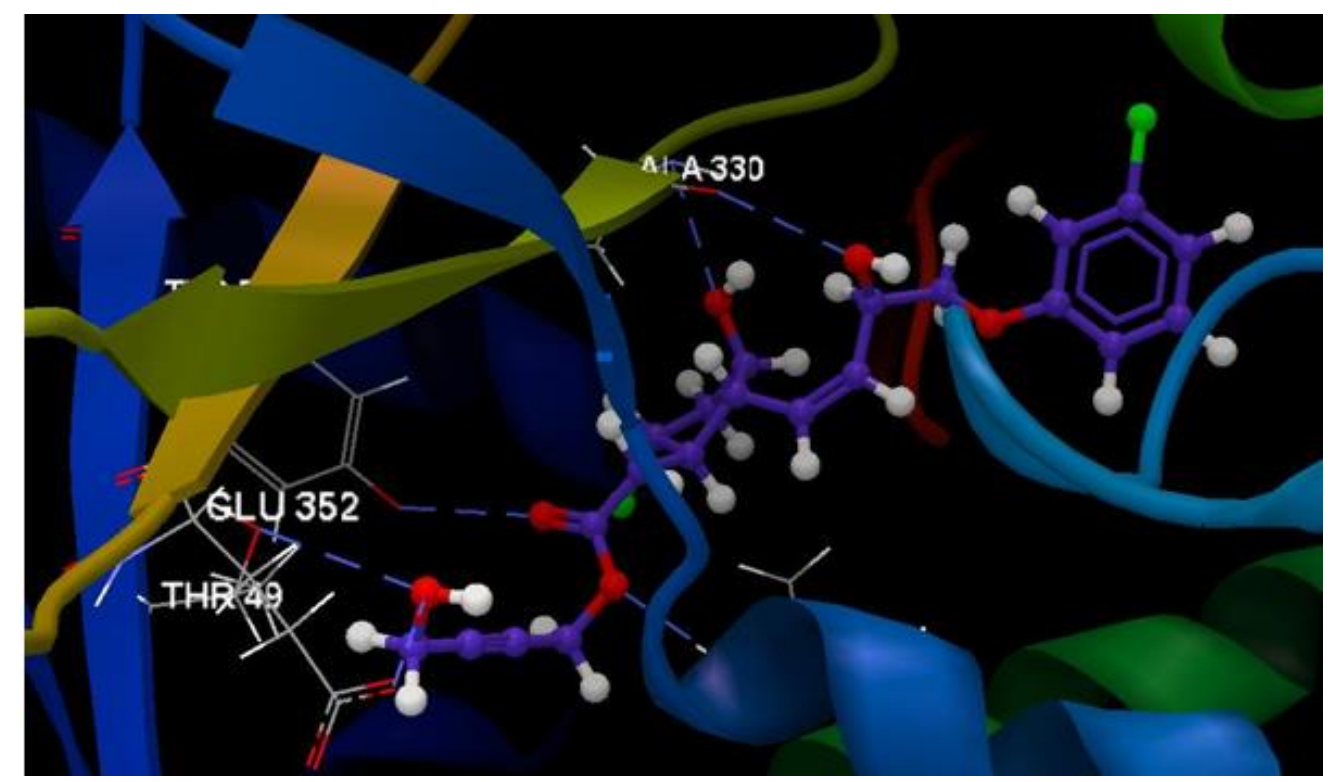

a 


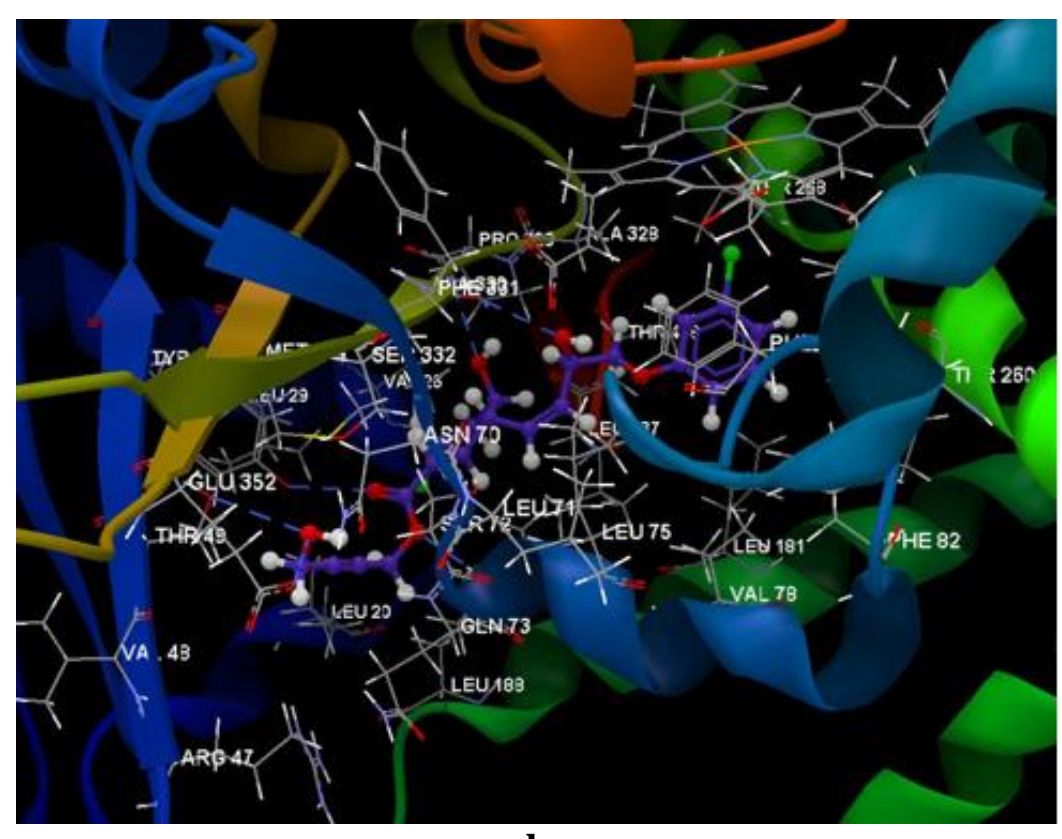

b

Figure 6. a) Hydrogen bonds between the residues of the ALA 330, ALA 74, TYR 51, THR 49, GLU 352 and the compound 3c;

b) Docking pose of the compound $3 \mathbf{c}$ interacting with amino acid residues in the binding site.

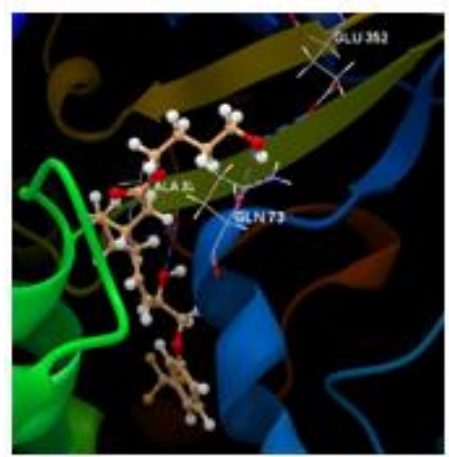

a

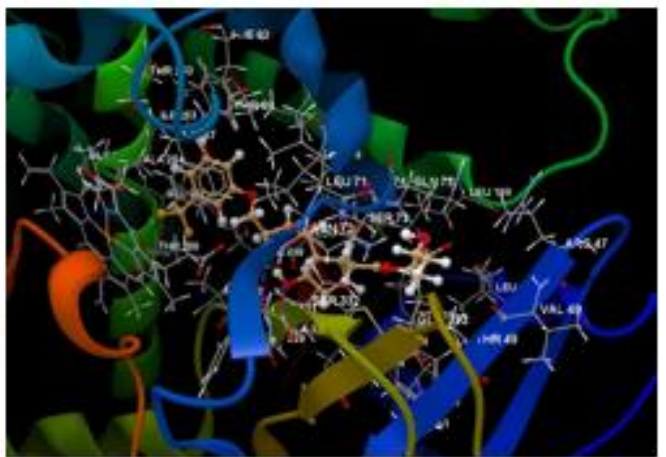

b

Figure 7. a) Hydrogen bonds between the residues of the ALA 330, GLN 73 and GLU 352 and the compound 2l; b) Docking pose of the compound $2 \mathbf{l}$ interacting with amino acid residues in the binding site

In fact, majority of 9 9 -halogenated ligands were found to have the same orientation with that of cocrystallized omeprazole and nocloprost, as can be observed in the Table 2 . The compounds $\mathbf{2 b}, \mathbf{2 d}, \mathbf{2 g}$, $\mathbf{2 h}$ and $\mathbf{2 i}$ adopted a different orientation than that of the co-crystallized and nocloprost.

It was observed that the best orientation is shown by the following $9 \beta$-halogenated compounds:

-3d, who reveals the best docking score -84.91 (RMSD $1.28 \AA$ ) and shows the occurrence of 5 hydrogen bonds with ALA 330 (2.987 and 3.280 ̊), TYR 51 (2.656 ̊) and with ARG 47 (3.053 and $3.280 \AA$ ) (Figure 4a);

-3b, who reveals the docking score -82.27 (RMSD $0.63 \AA$ ) and shows the occurrence of 5

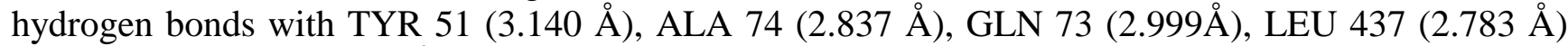
and with GLU 352 (2.907 ̊̊) (Figure 5a); 
-3c, who reveals the docking score -77.47 (RMSD $0.41 \AA$ ) and shows the occurrence of 6 hydrogen bonds with ALA 330 (3.047 and 3.167 ̊), ALA 74 (3.246 ̊), TYR 51 (3.059 ̊), THR 49 (3.319 $)$ and with GLU 352 (3.194 A) (Figure 6a);

-2l, who reveals the docking score -77.57 (RMSD $1.25 \AA$ ) and shows the occurrence of 5 hydrogen bonds with ALA 330 (3.113, 3.237 and $2.972 \AA)$, GLN 73 (2.985 ̊) and with GLU $352(2.795 \AA)$ (Figure 7a).

Table 2. The docking score and list of docking interactions between the ligand molecules and oxidoreductase enzyme receptor ID: $4 K E V$ using CLC Drug Discovery Workbench Software.

\begin{tabular}{|c|c|c|c|c|c|}
\hline $\begin{array}{l}\text { Compound } \\
\text { (Ligand) }\end{array}$ & Score & RMSD $^{*}$ & $\begin{array}{l}\text { Group } \\
\text { interaction }\end{array}$ & $\begin{array}{l}\text { Hydrogen } \\
\text { bond }\end{array}$ & $\begin{array}{c}\text { Bond } \\
\text { Length } \\
(\AA)\end{array}$ \\
\hline $\begin{array}{c}\text { Omeprazole } \\
\text { (co-crystalized) }\end{array}$ & -58.11 & 0.06 & $\begin{array}{l}\text { PHE 42, LEU 20, THR 49, TYR 51, LEU 29, LEU 88, PRO } \\
\text { 25, VAL 26, GLN 73, MET 354, SER 72, ALA 330, PRO } \\
\text { 329, LEU 75, ALA 74, LEU 437, GLU 435, LEU 181, VAL } \\
\text { 78, THR 438, THR 88, ALA 328, PHE 87, PHE } 82\end{array}$ & $\begin{array}{l}-\mathrm{Osp}^{3}(\mathrm{O} 2)-\mathrm{O} \mathrm{sp}^{3}-\text { TYR } 51 \\
-\mathrm{N} \mathrm{sp} \text { (NE1) - N sp } \mathrm{sp}^{2}-\text { ALA } 330\end{array}$ & $\begin{array}{l}2.946 \\
3.180\end{array}$ \\
\hline Nocloprost & -71.25 & 1.32 & $\begin{array}{l}\text { PHE } 81 \text {, PHE } 82 \text {, VAL } 78 \text {, LEU 181, LEU 75, THR 436, } \\
\text { LEU 437, ILE 263, PHE 87, ALA 264, GLU 267, THR 438, } \\
\text { THR 268, ALA 328, THR 327, PRO 329, PHE 331, ALA } \\
\text { 330, VAL 26, MET 354, LEU 29, TYR 51, ALA 74, GLN } \\
\text { 73, LEU 188, LEU 20, SER 72 }\end{array}$ & $\begin{array}{l}\text { - O } \mathrm{sp}^{3}(\mathrm{O} 1) \text { - O } \mathrm{sp}^{2} \text { - ALA } 330 \\
\text { - O } \mathrm{sp}^{2}(\mathrm{O} 4) \text { - N sp } \mathrm{s}^{2} \text { - ALA } 74 \\
\text { - O } \mathrm{sp}^{2}(\mathrm{O} 4) \text { - N sp } \mathrm{sp}^{2} \text { - GLN } 73\end{array}$ & $\begin{array}{l}3.079 \\
3.023 \\
3.204\end{array}$ \\
\hline $2 \mathbf{a}$ & -66.93 & 1.02 & $\begin{array}{l}\text { PHE } 87, \text { CYS } 400 \text {, LEU 75, SER 72, PHE 331, MET 354, } \\
\text { TYR 51, ALA 330, ALA 74, ALA 264, GLY 265, ILE 263, } \\
\text { GLU 267, THR 268, ALA 328, MET 185, LEU 437, THR } \\
\text { 438, THR 327, GLU 435, LEU 20, VAL 26, PRO 25, LEU } \\
\text { 29, LEU 188, PRO 329 }\end{array}$ & $-\mathrm{O} \mathrm{sp}{ }^{3}(\mathrm{O} 3)-\mathrm{O} \mathrm{sp}^{3}-\mathrm{TYR} 51$ & 2.880 \\
\hline $2 \mathbf{b}$ & -73.00 & 0.83 & $\begin{array}{l}\text { THR 88, PHE 87, PHE 82, VAL 78, LEU 75, SER 72, SER } \\
\text { 332, ALA 74, PHE 331, LEU 188, ALA 330, MET 354, } \\
\text { TYR 51, LEU 29, VAL 26, PRO 329, THR 327, THR 438, } \\
\text { THR 436, ALA 328, LEU 437, LEU 181, ALA 264, ILE } \\
\text { 263, GLU 267, THR } 268\end{array}$ & $-\mathrm{O} \mathrm{sp}^{2}(\mathrm{O} 6)-\mathrm{O} \mathrm{sp}^{3}-\mathrm{SER} 72$ & 2.995 \\
\hline $2 c$ & -70.67 & 1.18 & $\begin{array}{l}\text { GLY 265, THR 268, ALA 264, ILE 263, PHE 82, THR 438, } \\
\text { LEU 437, ALA 74, GLN 73, VAL 26, LEU 29, PHE 42, } \\
\text { ARG 47, LEU 188, LEU 20, VAL 78, THR 49, TYR 51, } \\
\text { MET 354, PRO 329, ALA 330, PHE 331, PRO 329, LEU } \\
\text { 75, SER 72 }\end{array}$ & $\begin{array}{l}-\mathrm{O} \mathrm{sp}^{3}(\mathrm{O} 1)-\mathrm{N} \mathrm{sp}^{2} \text { - ALA } 330 \\
\text { - O } \mathrm{sp}^{2}(\mathrm{O} 6) \text { - O } \mathrm{sp}^{3} \text { - TYR } 51 \\
\text { - O sp } \mathrm{sp}^{3}(\mathrm{O} 3) \text { - O } \mathrm{sp}^{3} \text { - TYR } 51 \\
\text { - O } \mathrm{sp}^{3}(\mathrm{O} 2)-\mathrm{N} \mathrm{sp}^{2} \text { - ALA } 74\end{array}$ & $\begin{array}{l}3.005 \\
3.255 \\
2.932 \\
3.320\end{array}$ \\
\hline $2 d$ & -74.92 & 0.78 & $\begin{array}{l}\text { LEU 20, LEU 188, ARG 47, PHE 42, THR 49, TYR 51, } \\
\text { GLU 352, MET 354, PHE 331, ALA 330, SER 72, GLN 73, } \\
\text { ALA 74, VAL 26, LEU 75, PRO 329, PHE 87, ALA 328, } \\
\text { THR 327, PHE 82, VAL 78, LEU 437, THR 438, PHE 82, } \\
\text { ALA 264, THR 260, THR 268, ILE 263, GLU 267, LEU } \\
\text { 181, THR 436 }\end{array}$ & $\begin{array}{l}\text { - } \mathrm{Osp} \mathrm{sp}^{3}(\mathrm{O} 3)-\mathrm{N} \mathrm{sp}^{2} \text { - ALA } 264 \\
\text { - } \mathrm{Osp}(\mathrm{s} 1)-\mathrm{O} \mathrm{sp}^{2} \text { - LEU } 437\end{array}$ & $\begin{array}{l}3.226 \\
2.863\end{array}$ \\
\hline $2 e$ & -74.67 & 0.83 & $\begin{array}{l}\text { PHE 81, PHE 82, VAL 78, LEU 181, PHE 87, ILE 263, } \\
\text { ALA 264, GLU 267, THR 268, THR 327, ALA 328, THR } \\
\text { 438, LEU 437, THR 436, PRO 329, PHE 331, VAL 26, } \\
\text { ALA 330, MET 354, LEU 29, TYR 51, THR 49, LEU 20, } \\
\text { SER 72, ALA 74, LEU 75, GLN 73, LEU 188 }\end{array}$ & $\begin{array}{l}-\mathrm{O} \mathrm{sp}{ }^{2}(\mathrm{O} 6)-\mathrm{O} \mathrm{sp}^{3}-\mathrm{SER} 72 \\
-\mathrm{Osp}(\mathrm{O} 3)-\mathrm{O} \mathrm{sp}^{3}-\mathrm{TYR} 51\end{array}$ & $\begin{array}{l}2.994 \\
2.979\end{array}$ \\
\hline $2 \mathrm{f}$ & -74.92 & 0.43 & $\begin{array}{l}\text { GLU 435, MET 185, PRO 25, LEU 20, LEU 29, VAL 26, } \\
\text { LEU 188, LEU 181, GLU 267, THR 268, ILE 263, ALA } \\
\text { 264, PHE 82, PHE 87, LEU 75, SER 72, PHE 331, MET } \\
\text { 354, TYR 51, LEU 356, GLN 73, ALA 330, ALA 328, } \\
\text { ALA 74, PRO 329, THR 327, THR 438, LEU 437, PHE } 42\end{array}$ & $\begin{array}{l}-\mathrm{O} \mathrm{sp}{ }^{3}(\mathrm{O} 1)-\mathrm{O} \mathrm{sp}^{3}-\mathrm{SER} 72 \\
-\mathrm{Osp}(\mathrm{O} 3)-\mathrm{O} \mathrm{sp}^{2}-\mathrm{TYR} 51\end{array}$ & $\begin{array}{l}3.285 \\
2.610\end{array}$ \\
\hline $2 \mathrm{~g}$ & -67.73 & 1.67 & $\begin{array}{l}\text { PRO 25, LEU 188, MET 185, GLU 435, THR 436, LEU } \\
\text { 181, VAL 26, LEU 437, ALA 74, VAL 78, THR 438, GLU } \\
\text { 267, ILE 263, THR 327, THR 268, ALA 264, PHE 82, PRO } \\
\text { 329, ALA 328, ALA 330, THR 88, PHE 87, PHE 331, SER } \\
\text { 332, MET 354, SER 72, MET 354, SER 72 }\end{array}$ & $-\mathrm{O} \mathrm{sp}{ }^{2}(\mathrm{O} 6)-\mathrm{O} \mathrm{sp}^{3}-\mathrm{SER} 72$ & 2.815 \\
\hline $2 \mathrm{~h}$ & -73.63 & 0.92 & $\begin{array}{l}\text { ARG 47, LEU 188, GLN 73, GLU 352, PHE 42, THR 49, } \\
\text { LEU 20, SER 72, ALA 74, LEU 75, VAL 78, PHE 82, LEU } \\
\text { 181, PHE 87, THR 260, ILE 263, ALA 264, LEU 437, THR } \\
\text { 436, THR 438, SER 332, MET 354, TYR 51, VAL 26, ALA } \\
\text { 330, PRO 329, ALA 328, THR 327, THR 268, PHE } 331\end{array}$ & $\begin{array}{l}\text { - O sp } \mathrm{sp}^{3}(\mathrm{O} 3) \text { - N sp } \mathrm{sp}^{2} \text { - ALA } 264 \\
\text { - } \mathrm{Osp}\left(\mathrm{s} \mathrm{s}^{3}(\mathrm{~s}) \text { - } \mathrm{sp}^{3} \text { - LEU } 437\right.\end{array}$ & $\begin{array}{l}3.110 \\
3.081\end{array}$ \\
\hline $2 \mathbf{i}$ & -72.29 & 1.60 & $\begin{array}{l}\text { GLY 265, GLU 267, ILE 263, THR 268, ALA 264, THR } \\
\text { 327, ALA 328, PHE 87, PRO 329, PHE 331, ALA 330, } \\
\text { PHE 82, THR 438, VAL 78, LEU 437, GLU 435, MET 185, } \\
\text { PRO 25, LEU 188, LEU 29, PHE 42, GLN 73, VAL 26, } \\
\text { ALA 74, SER 72, MET 354, TYR 51, LEU 75 }\end{array}$ & $\begin{array}{l}\text { - O sp } \mathrm{sp}^{3}(\mathrm{O} 1)-\mathrm{O} \mathrm{sp}{ }^{3}-\mathrm{SER} 72 \\
-\mathrm{Osp}^{2}(\mathrm{O} 5)-\mathrm{N} \mathrm{sp} \mathrm{s}^{2} \text { THR } 438\end{array}$ & $\begin{array}{l}3.259 \\
3.179\end{array}$ \\
\hline
\end{tabular}




\begin{tabular}{|c|c|c|c|c|c|}
\hline $2 \mathbf{j}$ & -71.13 & 1.36 & $\begin{array}{l}\text { LEU 29, TYR 51, VAL 26, MET 354, ALA 330, PRO 329, } \\
\text { THR 327, ALA 328, THR 438, PHE 331, THR 268, GLU } \\
\text { 267, GLY 265, ALA 264, ILE 263, PHE 87, PHE 82, VAL } \\
\text { 78, LEU 181, LEU 75, LEU 71, SER 72, ALA 74, ASN 70, } \\
\text { GLN 73, LEU 188, ARG 47, ALA 44, VAL 48, GLU 352, } \\
\text { THR 49, LEU 20, PHE 42, LEU 20, SER 332, THR 436, } \\
\text { LEU } 437\end{array}$ & 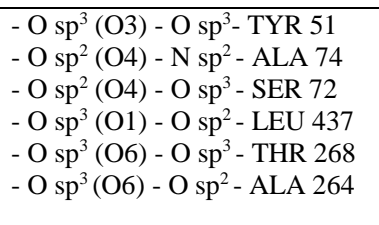 & $\begin{array}{l}3.199 \\
3.198 \\
2.928 \\
2.544 \\
2.659 \\
2.819\end{array}$ \\
\hline $2 \mathbf{k}$ & -75.03 & 0.76 & $\begin{array}{l}\text { HIS 266, THR 268, GLU 267, ALA 264, ILE 263, ALA } \\
\text { 328, THR 438, PHE 87, PHE 82, LEU 181, VAL 78, PRO } \\
\text { 329, ALA 330, PHE 331, LEU 437, LEU 75, ALA 74, SER } \\
\text { 72, GLN 73, LEU 188, LEU 20, PHE 42, PRO 25, TYR 51, } \\
\text { LEU 29, MET 354, VAL 26, SER 332 }\end{array}$ & $\begin{array}{l}-O \mathrm{sp}^{3}(\mathrm{O} 6)-\mathrm{O} \mathrm{sp}^{2} \text { - LEU } \\
-\mathrm{Osp}(\mathrm{O} 1)-\mathrm{O} \mathrm{sp}^{2} \text { - ALA } 330 \\
\text { - O } \mathrm{sp}^{3}(\mathrm{O} 3)-\mathrm{O} \mathrm{sp}^{2} \text { - ILE } 263\end{array}$ & $\begin{array}{l}2.641 \\
3.035 \\
3.086\end{array}$ \\
\hline 21 & -77.57 & 1.25 & $\begin{array}{l}\text { PHE 82, THR 260, THR 88, VAL 78, ILE 263, PHE 87, } \\
\text { GLY 265, ALA 26, GLU 267, THR 268, ALA 328, PHE } \\
\text { 331, ALA 330, PRO 329, SER 332, MET 354, VAL 26, } \\
\text { GLU 352, THR 49, VAL 48, ARG 47, LEU 20, PRO 25, } \\
\text { LEU 437, ASN 70, SER 72, THR 438, LEU 71, LEU 75, } \\
\text { ALA 74, MET 185, GLN 73, LEU 188, LEU 29, TYR 51 }\end{array}$ & 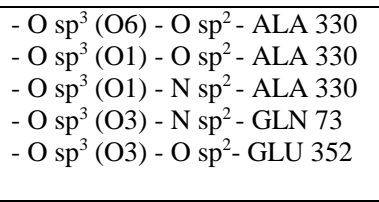 & $\begin{array}{l}3.113 \\
3.237 \\
2.972 \\
2.985 \\
2.795\end{array}$ \\
\hline 3a & -75.09 & 1.42 & $\begin{array}{l}\text { GLY 265, CYS 400, ALA 264, THR 268, ILE 263, GLU } \\
\text { 267, PHE 87, ALA 328, THR 438, VAL 78, LEU 75, LEU } \\
\text { 437, GLU 435, MET 185, ALA 74, PRO 329, PHE 331, } \\
\text { ALA 330, SER 72, GLN 73, LEU 188, VAL 26, PRO 25, } \\
\text { LEU 20, LEU 29, TYR 51, LEU 29, MET } 354\end{array}$ & - O sp3 (O1) - O sp2 - ALA 330 & 2.986 \\
\hline $3 \mathbf{b}$ & -82.27 & 0.63 & $\begin{array}{l}\text { ASN 70, PHE 87, LEU 71, SER 332, GLU 352, PHE 82, } \\
\text { THR 260, LEU 75, SER 72, GLN 73, ARG 47, THR 49, } \\
\text { MET 354, VAL 48, ALA 330, ALA 328, PRO 329, THR } \\
\text { 268, LEU 181, THR 438, LEU 437, LEU 188, MET 185, } \\
\text { VAL 26, TYR 51, LEU 29, PRO 25, LEU 20, GLU 435, } \\
\text { ILE 263, VAL 78, ALA } 264\end{array}$ & $\begin{array}{l}\text { - O sp3 (O6) - O sp2 - GLU } 352 \\
\text { - O sp3 (O6) - N sp2 - GLN 73 } \\
\text { - O sp2 (O5) - N sp2 - ALA 74 } \\
\text { - O sp3 (O2) - O sp3 - TYR 51 } \\
\text { - O sp3 (O1) - O sp2 - LEU } 437\end{array}$ & $\begin{array}{l}2.907 \\
2.999 \\
2.837 \\
3.140 \\
2.783\end{array}$ \\
\hline $3 c$ & -77.47 & 0.41 & $\begin{array}{l}\text { GLY 265, ALA 264, THR 268, ALA 328, PRO 329, PHE } \\
\text { 331, ALA 330, THR 438, ILE 263, THR 260, PHE 87, LEU } \\
\text { 437, VAL 26, SER 332, MET 354, SER 332, MET 354, } \\
\text { LEU 29, TYR 51, GLU 352, THR 49, LEU 20, VAL 48, } \\
\text { ARG 47, LEU 188, GLN 73, ALA 74, LEU 71, ASN 70, } \\
\text { SER 72, LEU 75, LEU } 181\end{array}$ & $\begin{array}{l}\text { - O sp3 (O5) - O sp2 - GLU } 352 \\
\text { - O sp3 (O5) - O sp3 - THR } 49 \\
\text { - O sp2 (O4) - O sp3 - TYR } 51 \\
\text { - O sp3 (O2) - N sp2 - ALA } 74 \\
\text { - O sp3 (O1) - N sp2 - ALA } 330 \\
\text { - O sp3 (O6) - O sp2 - ALA } 330\end{array}$ & $\begin{array}{l}3.194 \\
3.319 \\
3.059 \\
3.246 \\
3.167 \\
3.047\end{array}$ \\
\hline 3d & -84.91 & 1.28 & $\begin{array}{l}\text { TYR 51, PHE 42, LEU 29, ALA 44, LEU 17, ARG 47, } \\
\text { LEU 20, PRO 25, LEU 20, VAL 26, MET 354, ALA 330, } \\
\text { PRO 329, PHE 331, ALA 328, SER 72, THR 438, LEU } \\
\text { 437, GLN 73, LEU 188, MET 185, ALA 74, LEU 75, THR } \\
\text { 268, LEU 181, VAL 78, ILE 263, PHE 82, ALA 264, PHE } \\
\text { 87, GLU 267, PHE 81, GLU 435 }\end{array}$ & $\begin{array}{l}\text { - O sp3 (O5) - N sp2 - ARG } 47 \\
\text { - O sp3 (O5) - N sp2 - ARG } 47 \\
\text { - O sp2 (O4) - O sp3 - TYR } 51 \\
\text { - O sp3 (O1) - N sp2 - ALA } 330 \\
\text { - O sp3 (O6) - O sp2 - ALA } 330\end{array}$ & $\begin{array}{l}3.280 \\
3.053 \\
2.656 \\
3.280 \\
2.987\end{array}$ \\
\hline
\end{tabular}

\section{Conclusions}

Prostaglandin analogues substituted with a $9 \beta$-halogen and with an ester group with a diol at the C6 carbon atom, previously synthesized, were used in a molecular docking study to determine their potential cytoprotective (anti-ulcer) activity. The study has been done with CLC Drug Discovery Workbench 2.4. software and an oxidoreductase enzyme receptor, chosen from the Protein Data Bank, ID: $4 K E W$. (www.rcsb.org). In the study we used as standard two recognized drugs, omeprazole (cocrystallized with the enzyme) and nocloprost. The $9 \beta$-halogenated prostaglandin analogs $\mathbf{2 a - 2 l}$ and 3a3d were finally docked. Nocloprost and all $9 \beta$-halogenated compounds had docking score greater than that of omeprazole. The majority of $9 \beta$-halogenated analogs have a docking score greater than that of nocloprost, with the exception of the compounds $\mathbf{2 a}, \mathbf{2 c}, \mathbf{2 g}$ and $\mathbf{2 j}$. The compounds $\mathbf{2 b}, \mathbf{2 d} \mathbf{- 2 f}, \mathbf{2 h}-\mathbf{2 i}$, 2k-2l, 3a-3d had a greater docking score than that of nocloprost; this indicate that the compounds could have potential cytoprotective (anti-ulcer) activity. A few correlations between docking score and substituents on the prostaglandin skeleton have been done.

\section{References}

1.VANTRAPEN, G., JANSENS, J., POPIELA, P., KULIG, J., TYTGAT, G. N., HUIBREGTSE, K., LAMBERT, R., PAUCHARD, J. P., ROBERT, A., Gastroenterology, 83, 1982, p. 357.

2.HAWKEY, C. J. in: Advances in Drug Therapy of Gastrointestinal Ulcerations, Garner, A and Whittle, B.J.R. (Eds.) Wiley \& Sons, Chichester), 1989, p. 89.

3.HAWKEY, C. J., KARRASCH, J.A., SZCZEPAÑSKI, L., WALKER, D. G., BARKUN, A., SWANNELL, A. J., YEOMANS, N. D., N. Engl. J. Med., 338, no. 11, p. 1998, 727. 
4.BIANCHI PORRO, G., PARENTE, F., HENTSCHEL, E., BENNANI, A., SEBTI, F., CHERKAOUI, A., DEMYTTENAERE, M., GOUEROU, H., BLASI, A., DARNIS, F., STADAAS, J., GLIKMANAS, M., FRANCAVILLA, A., Scand. J. Gastroenterol Suppl., 164, 1989, p. 219. 5.BIANCHI PORRO, G., PARENTE, F. in: Gastrointestinal Cytoprotection by Prostaglandins, BIANCHI PORRO, G. and DAJANI, E. Z. (Eds) (Cortina Internat., Amsterdam), 1987, p 39. 6.RADUCHEL, B., SKUBALLA, W., VORBRUGGEN, H., DE 3543991A, 1985.

7.SKUBALLA, W., RADUCHEL, B., SCHWARZ, N., VORBRUGGEN, H., ELGER, W., DE 3148743 A1/1983.

8.SKUBALLA, W., RADUCHEL, B., VORBRUGGEN, H., ELGER, W., LOGE, O., SCHILLINGER, E., US5079259A/1992.

9.SKUBALLA, W., RADUECHEL, B., SCHWARZ, N., ELGER, W., TOWN, M. H., VORBRUEGGEN, H., US4789685 (A)/1988.

10.KONTUREK, S. J., BRZOZOWSKI, T., DROZDOWICZ, D., KRZYZEK, E., GARLICKI, J., MAJKA, J., DEMBINSKI, A., STACHURA, J., AMON, I., Eur. J. Pharmacol., 195, 1991, p. 347. 11.OKAMURO, S., KATAYAMA, S., ONO, N., SATO, F., Tetrahedron Asimmetry, 3, no. 12, 1992, p. 1525.

12.THIERAUCH, K. H., STURZEBECHER, C., SCHILLINGER, E., REWINKEL, H., RADUCHEL, B., SKUBALLA, W., VORBRUGGEN, H., Prostaglandins, 35, no. 6, 1988, 855.

13.ARRONIZ, C.E., GALLINA, J., MARTINEZ, E., MUCHOWSKI, J., VELARDE, E., Prostaglandins, 16, no. 1, 1978, 47.

14.ITO, S., OKUDA, E., SUGAMA, K., NEGISHI, M., HAYASHI, O., Br. J. Pharmacol., 99, 1990, p. 13.

15.TĂNASE, C., COCU, F., DRĂGHICI, C., CĂPROIU, M.T., MAGANU, M., Rev. Chim., 67, (3), 2016, p. 468.

16.TĂNASE, C., COCU, F., DRĂGHICI, C., CĂPROIU, M.T., MAGANU, M., Patent request RO 129720 A2/2013.

17.KONISHI, Y., KAWAMURA, M., EP 0386901 A1/1990.

18.CLC Drug Discovery Workbench, available from http://www.clcbio.com

19.BUTHER, C. F., PEET, C., MASON, A. E., VOICE, M. W., LEYS, D., MUNRO, A. W., J. Biol. Chem., 288 no. 35, 2003, p. 25387.

20.KORB, O., STÜTZLE, T., EXNER, T.E., J. Chem. Inf. Model, 49, 2009, p. 84.

21.TĂNASE, I. C., COCU, F., DRĂGHICI, C., HANGANU, A., PINTILIE, L., MAGANU, M., VOLOBUEVA, A., SINEGUBOVA, E., ZARUBAEV, V. V., NEYTS, J., JOCHMANS, D., SLITA, A, V., Molecules, 24, 2019, p. 2446/1-20.

22.LIPINSKI, C. A., LOMBARDO, F., DOMINY, B. W., FEENEY, P. J., Adv. Drug Deliv. Rev., 46, no. $1-3,2001$, p. 3.

23.LIPINSKI, C. A., Drug Discovery Today: Technologies, 1, no. 4, 2004, p. 337.

$\overline{\text { Manuscript received: } 4.12 .2019}$ 